\title{
PRAGMATIK BENTANG ALAM PEDESAAN \\ ( STUDI KASUS DUSUN BENDOSARI, KEC. PUJON, KAB. MALANG)
}

\author{
Chairil Budiarto Amiuza, Yusfan A. Yusran, Lisa Dwi W., Indyah Martiningrum \\ Jurusan Arsitektur/Fakultas Teknik Universitas Brawijaya \\ chairilbudiartoamiuza@yahoo.co.id
}

\begin{abstract}
ABSTRAK
Potensi dan kondisi lingkungan pedesaan Bendosari, di Kecamatan Pujon, Kabupaten Malang, nampaknya ada kecenderungan ketidak-setimbangan dan selarasan Estetika Bentang Alamnya. Salah satu upaya pelestarian menjaga kesetimbangan dan keselarasan bentang alamnya, melalui kajian bentang alam lingkungan pedesaan di daerah tersebut. Metoda yang digunakan adalah metode penelitian secara kualitatif, melalui survey dan wawancara untuk memperoleh konfigurasi visual dan fisikal dan interelasi bentang alamnya dengan fungsi-guna bagi masyarakat desanya. Interelasi dan organisasi visual dan fisikal lingkungan alam dan lingkungan buatan pedesaan tersebut, terkait tersusun erat secara fisik, visualnya mengikuti fisik dan masih didominasi visual alami kecuali di pusat desanya. Fungsi-guna pada konfigurasi visual dan fisikal yang ada tersebut oleh sebagian besar penduduk pedesaan, masih secara alami dan tradisional namun sebagian yang dipusat desa sudah secara artifisial dan modern.
\end{abstract}

Kata Kunci: Pragmatik, Sintaksis, Estetika bentang alam, Desa bendosari

\begin{abstract}
Conditions and the potential for rural environments Bendosari, Pujon district, Malang, there seems to be a tendency lack balance Landscape Aesthetics and harmony of its. One effort to maintain balance and harmony preservation of the landscape, through the study of the rural landscape in the area. The method that used was a qualitative research method, through surveys and interviews to obtain visual and physical configurations and interrelationships landscape with functions in order for the village community. The interrelation of visual and physical organization of the natural environment and the rural built environments, arranged closely related to the physical, visual and physical follow natural visual dominated except in the village center. Functions for the visual and physical configurations that exist are the majority of the rural population, it is still natural and traditional, but most of the villagers are artificially centered and modern.
\end{abstract}

Keywords: Pragmatics, Syntax, Landscapes aesthetic, Bendosari village

\section{Pendahuluan}

Potensi dan kondisi lingkungan pedesaan Bendosari di Kecamatan Pujon, Kabupaten Malang, nampaknya ada kecenderungan ketidak-setimbangan dan selarasan estetika bentang alamnya. Hal ini akibat kawasan alami semakin tergerus dan terdesak 
oleh kawasan buatan, juga dipicu dan didukung oleh ketidak-kurang pedulian masyarakat desa dan masyarakat diluarnya akan manfaat-guna serta arti-makna keadaan bentang alam lingkungan dari sisi estetika, ekologi dan komunitasnya. Hal itu perlu dilakukan tindakan pencegahan dan perlambatan secara mendasar dan menyeluruh dari semua pihak yang terlibat didalamnya.

Salah satu upaya pelestarian menjaga kesetimbangan dan kese-larasan bentang alam tersebut yang dapat dilakukan oleh akademisi, melalui kajian bentang alam lingkungan pedesaan di daerah tersebut. Dimulai dari penelusuran kondisi dan potensi bentang alamnya, mencari-temukan manfaat-guna dan arti-makna unsur-unsur bentang alamnya bagi masyarakat desa dan lingkungan tersebut.

Penelitian ini hendak mengkaji konfigurasi visual dan fisikal unsur unsur bentang alam di Desa Bendosari, kecamatan Pujon, kabupaten Malang, interelasi dan organisasi visual dan fisikal lingkungan alam dan lingkungan buatan pedesaan tersebut, serta fungsi yang digunakan pada konfigurasi visual dan fisikal yang ada tersebut oleh penduduk pedesaan.

\section{Bahan dan Metode}

\subsection{Tinjauan Pustaka}

\subsubsection{Pragmatik dalam Arsitektur}

Dalam lingkup budaya Umberto Eco, semiotik dapat dipakai untuk mengamati berbagai tanda yang bersifat empiris dan indrawi (Eco, 1984). Tanda tanda yang bersifat empiris anatu indrawi dapat mencakup tanda tanda lingkungan alam seperti lansekap, cuaca, peristiwa alam, lingkungan artifisial seperti arsitektur permukiman, rumah tinggal, eksterior, interior, ragam hias dan sebagainya. Kajian semiotika meliputi seluruh wahana intelektual manusia, tanda alamiah dan peradaban yang dikenal sebagai ranah budaya, antara lain:

- Komunikasi visual (Visual Communication), kajian yang meliputi sistem grafis, warna, tanda tanda ikon, simbol dan sebagainya.

- Sistem obyek (Systems of Objects), meliputi arsitektur, kota, lansekap dan sebagainya.

Bagi Pierce, semiotika adalah sinonim logika. Artinya bahwa manusia hanya berfikir dengan tanda (Roland, 1985). Ilmu tanda atau semiotika dapat dijadikan alat untuk menelusuri sesuatu dan menghasilkan sesuatu berupa tanda tanda atau simbol simbol. Dalam uraian selanjutnya, bahwa tanda tanda tersebut berdasarkan relasinya terdiri dari:

- Semiotik Sintaksis, aktifitas yang mempelajari tanda dalam sistim tanda yang lain yang menunjukkan kesamaan atau kerjasama.

- Semiotik Semantik, mempelajari hubungan antara tanda dan maknanya atau denotasi dan konotasi dari tanda tanda tersebut.

- Semiotik Pragmatik, mempelajari hubungan tanda dengan pemakainya.

Tanda tanda visual dan fisikal yang terdapat dalam tatanan obyek lingkungan alam dan buatan atau dapat disebut bentang alam itu dapat diamati dan ditelusuri konfigurasi, interelasi dan organisasi unsur unsurnya dalam aspek praagmatik yaitu manfaat-guna serta fungsi bagi pemakainya dalam tautan budayanya.

\subsubsection{Pendekatan Pragmatik}

Aspek pragmatik sering menjadi kriteria utama dalam realitas desain arsitektur dan bentang alam. Kenyataan tersebut menentukan karya arsitektur bermanfaat atau tidak (Zahnd, 2009). Aspek pragmatik arsitektur dan Bentang Alam mencakup variabel sebagai berikut: 
- Yang membangun

- Penghuni/pemakai

- Fungsi/guna

- Waktu/lama dibangun

- Lokasi

- Teknik membangun

- Teknik bangunan

- Pihak yang terlibat

- Sarana dan prasarana.

Variabel diatas sebagai aspek dari pendekatan pragmatik bentang alam pedesaan dapat dihadapkan kepada variabel bentang alam, sehingga dapat ditelusuri dan ditemukan unsur unsur bentang alam di lingkungan pedesaan yang spesesifik sebagai bentuk karakter dari bentang alam pedesaan yang dikaji.

\subsubsection{Unsur-Unsur Bentang Alam}

Bentang alam merupakan salah satu wujud budaya, sehingga bentang alam suatu kawasan bergantung dari kebudayaan daerahnya, terkait dengan manusia, aktifitas dan lingkungannya. Bentang alam nusantara adalah wujud budaya nusantara, yang memiliki macam dan karakteristik yang sangat beraneka ragam, karena nusantara memiliki alam lingkungan dengan kebudayaan yang khas dan beragam. Bentang alam mencakup kawasan kota maupun pinggiran kota dan pedesaan. Kawasan pedesaan yang masih menjadi mayoritas kawasan di nusantara dapat dipastikan memiliki karakteristik bentang alam yang hampir serupa. Semua suku dari berbagai daerah di Nusantara memiliki pandangan hidup-filosofi hidup yang diturunkan pada generasi penerusnya melalui simbol-simbol dalam wujud fisik lingkungan binaannya, termasuk dalam pola tatanan bentang alamnya.

Untuk mengkaji karakteristik bentang alam suatu lingkungan dapat dilakukan dengan mengidentifikasi unsur unsurnya yang ada dalam suatu kawasan (Page et al, 1998), komponen-komponen itu antara lain :

- Sistem dan ciri alam (Natural Systems and Features); ciri-ciri alam yang mempengaruhi perkembangan lansekap dan bentukan yang dihasilkan alam pada kawasan (geomorfologi, geologi, hidrologi, ekologi, iklim, vegetasi setempat).

- Organisasi keruangan (Spatial Organization); pengaturan ele-men-elemen pencipta bidang dasar, bidang vertikal dan bidang atap yang membentuk dan menegaskan sistem ke-ruangan dalam skala tapak maupun kawasan.

- Penggunaan lahan (Land Use); organisasi, bentuk dan bentuk-an lansekap terkait dengan penggunaan lahan.

- Tradisi budaya (Cultural Traditions); kegiatan kegiatan yang mempengaruhi peng-gunaan dan pola pembagian lahan, bentuk bangunan, dan penggunaan material.

- Penataan kluster (Cluster Arrangement); lokasi bangunan dan struktur lain dalam kawasan.

- Sirkulasi (Circulation); ruang-ruang, fitur-fitur, dan material-material yang membentuk sistem pergerakan.

- Topografi (Topography); kon-figurasi tiga dimensi per-mukaan lansekap yang dicirikan oleh struktur yang terbentuk dan orientasinya.

- Vegetasi (Vegetation); tana-man-tanaman asli atau baru berupa pohon, semak, tana-man rambat, rumput, dan tanaman herbal. 
- Bangunan dan struktur (Buildings and Structures); konstruksi tiga dimensi seperti bangunan umum, jalan, rumah, jembatan.

- View dan vista (Views and Vistas); fitur-fitur alami atau buatan yang dapat menciptakan kontrol pandangan.

- Fitur-fitur air buatan (Constructed Water Features); fitur buatan dan elemenelemen air untuk tujuan fungsional dan estetika.

- Fitur-fitur berskala kecil (Small Scale Features); kombinasi fungsi dan estetik dengan elemen-elemen detil yang memberikan keanekaragaman.

- Kawasan arkeologis (Archeological Sites); kawasan yang didalamnya terdapat sisa peninggalan masa lampau yang bernilai historis.

Unsur unsur Bentang Alam disamping memiliki ciri-ciri fisikalnya, juga mengandung nilai nilai yang memberikan citra visual bagi lingkungan masyarakatnya, sehingga antara ciri fisikal dan nilai visual terdapat kesetimbangan dan keselarasan kehidupan bentang alam tersebut. Nilai-nilai Visual tersebut meliputi nilai estetika dan ekologi vegetasi.

\subsection{Metode Penelitian}

Untuk mengetahui elemen-elemen lingkungan yang khas, unik dan memiliki unsur-unsur bentang alam yang dipahami setempat, data dari obsevasi lapangan dan hasil wa-wancara pertama diolah dengan menggunakan rekonstruksi konfigurasi visual dan narasi deskriptif. Dari hasil analisis akan diperoleh daftar elemen-elemen lingkungan atau obyek-obyek visual dan fisikal yang ada di lapangan dan disebutkan oleh para responden dalam wawancara dengan total jumlah sampel yang terpilih di lingkungan tersebut.

Selanjutnya sebagaimana diuraikan pada subbab terdahulu, elemen-elemen lingkungan yang telah terpilih tersebut difoto, dimontase, digambar dan direkonstruksi untuk kemudian dijelaskan oleh masyarakat dengan menggunakan tabulasi gambar dan narasi. Data yang terkumpul pada bagian ini kemudian dianalisis dengan menggunakan metode sintaksis (semiotika bahasa rupa dan arsitektur) sehingga diperoleh gambaran pengelompokan obyek-obyek visual yang ada di wilayah studi dalam rentang kesesuaiannya dengan bahasa arsitekturnya.

Akhirnya, untuk mengetahui hubungan antara kelompok-kelompok elemenelemen lingkungan dari hasil sintaksis untuk tiap-tiap kelompok obyek visual tersebut digunakan metode pragmatik. Dengan meng-gunakan metode analisis ini kita dapat menentukan tingkat kontribusi dari masing-masing kriteria yang diperoleh arti dan fungsi elemen elemen ling-kungan bagi masyarakatnya.

\section{Hasil dan Pembahasan}

Desa Bendosari terletak di bagian barat Kabupaten Malang. Jarak dari lbukota Kecamatan $11 \mathrm{Km}$ dan dari lbukota Kabupaten $37 \mathrm{Km}$. Topografi desa adalah perbukitan / lereng pegunungan, terbagi dalam 5 Dusun (Cukal, Dadapan Wetan, Dadapan Kulon, Ngeprih-Tretes), 5 RW dan 23 RT. Batas Wilayah Desa adalah: Utara : Wilayah Perhutani; Barat: Wilayah Perhutani / Kecamatan Ngantang; Selatan : Wilayah Per-hutani; Timur: Wilayah Perhutani / Desa Sukomulyo.

Desa Bendosari berbatasan langsung dengan kawasan hutan perhutani. Beberapa wilayah hutan perhutani di Desa Bendosari sudah berubah fungsi menjadi ladang yang banyak ditanami tumpang sari oleh masyarakat. Pengambilan kayu bakar juga dilakukan oleh masyarakat untuk memenuhi kebutuhan memasak di rumah tangga. Berdasarkan kepemilikan lahannya wilayah Bendosari dapat dibagi menjadi tiga bagian yaitu masyarakat Magersaren, Pesanggem dan petani pemilik lahan. Magersaren adalah 
masyarakat yang tinggal dikawasan hutan karena tidak memiliki lahan baik perumahan maupun lahan pertanian. Kelompok Pesanggem adalah kelompok yang tingggal diluar kawasan hutan namun mempunyai lahan garapan di areal hutan. Petani secara umum disebutkan kelompok masyarakat yang mempunyai lahan perumahan dan lahan pertanian sendiri. Disamping itu, masyarakat Bendosari banyak tergantung pada peternakan sapi perah.

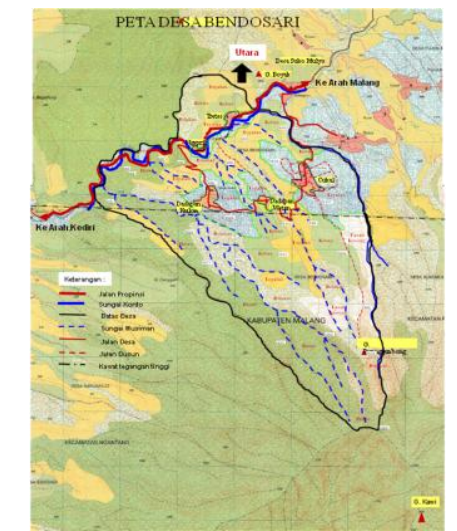

Gambar 1. Peta Desa Bendosari

(Sumber: kelurahan Bendosari)

Hamparan lahan di wilayah ini masih memungkinkan untuk dikembangkan ke arah pertanian dengan tetap mempertahankan fungsi-fungsi ekologis. Pengembangan tanaman keras dibawah tegakan hutan maupun di lahan pertanian merupakan contoh pemanfaatan lahan yang cukup bagus, selain dapat meningkatkan perekonomian masyarakat, secara ekologi tanaman ini juga dapat me-ngurangi tingkat erosi tanah sehingga dapat mempertahankan tingkat ke-suburan. Banyaknya jumlah mata air yang berada diwilayah hutan memberikan dukungan yang positif untuk pengembangan pertanian di-kawasan ini. Sumber-sumber air ini juga merupakan sumber penghidupan bagi masyarakat desa penyangga hutan maupun di daerah hilir.

\subsection{Bentang Alam Desa Bendosari}

\subsubsection{Sistim dan Ciri Alam (Natural System \& Features)}

Kondisi topografi alam di Desa Bendosari mempengaruhi bentukan lansekap pedesaan secara ke-seluruhan. Area perkebunan dan hutan terletak di kontur yang lebih tinggi sesuai petak-petak lahan secara alami. Kondisi geologi dan iklim setempat yaitu tanah dan iklim tropis pegunungan yang sejuk dan dingin mempengaruhi jenis vegetasi yang dibudidayakan di desa Bendosari, yaitu khususnya tanaman apel baru dikembangkan, tomat dan sayur mayur seperti wortel, kentang, lobak, lombok dan kubis serta padi dan jagung.

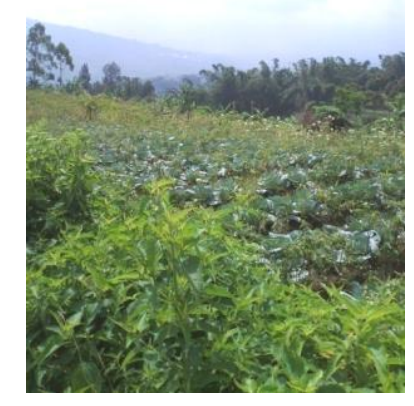




\subsubsection{Organisasi keruangan (Spatial Organization)}

Secara spasial, zonasi keruangan pada lansekap Desa Bendosari terbagi menjadi zona buatan (build Evironment), semi buatan dan Alami (Natural Environment). Pembagian zonasi ini dipengaruhi juga oleh kronologis pembentukan lansekap tersebut, yaitu area yang pertama kali dihuni yaitu area permukiman warga saat ini, dijadikan sebagai zona pusat desa bersifat publik. Semakin naik ke kontur yang lebih tinggi, yaitu area permukiman, beserta kebun dan kandang sapi, merupakan zona semi publik. Sedangkan area diatasnya lahan pertanian, perkebunan dan kehutanan yaitu area hutan Perhutani, merupakan zona privat dari keseluruhan lansekap di desa Bendosari. Pembagian organisasi keruangan tersebut dapat dilihat pada gambar berikut:

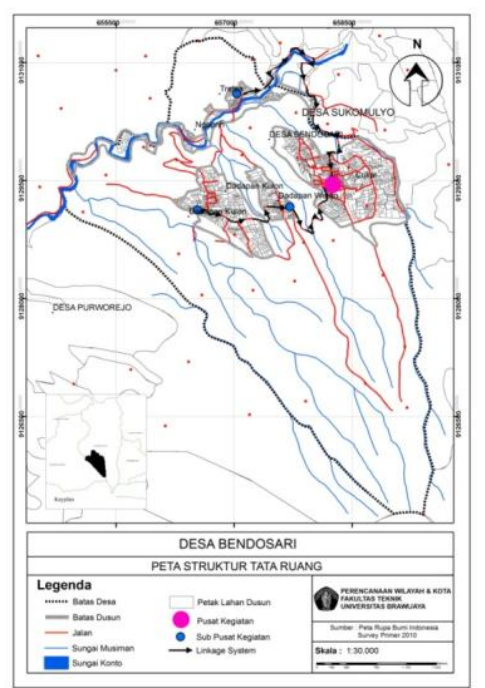

Gambar 3. Organisasi keruangan

(Sumber: Kelurahan Bendosari)

\subsubsection{Penggunaan lahan (Land Use)}

Penggunaan lahan pada lansekap di Dusun Junggo, terbagi menjadi lahan untuk permukiman warga, lahan perkebunan, serta area hutan milik Perhutani. Adapun pola pembagiannya adalah sebagai berikut:

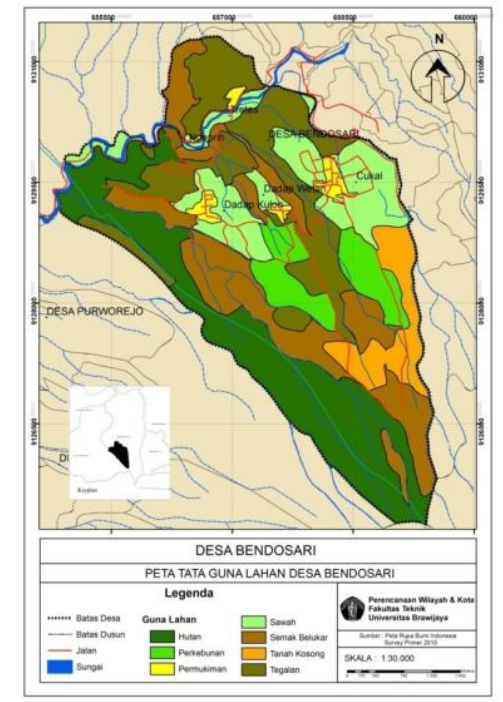

Gambar 4. Peta Guna-Lahan

(Sumber: Kelurahan Bendosari) 


\subsubsection{Tradisi budaya (Cultural Traditions)}

Mayarakat Desa Bendosari adalah masyarakat petani yang terdiri dari beberapa suku anatara lain suku Jawa asli dataran tinggi, suku jawa pendatang dan ada sebagian suku Bali. Mereka hidup dan berkehidupan dengan mengolah tanah, bercocok tanam dan berternak sapi perah, maka mereka mempunyai tradisi budaya yang melekat dalam diri mereka adanya macro kosmos dan micro kosmos.

Mereka punya kepercayaan bahwa yang mengatur seluruh kehidupan manusia, bumi air dengan segala isinya oleh sang pencipta, sedangkan manusia berkewajiban memelihara, memanfaatkan dan me-lestarikannya atas berkah yang biberikan Sang pencipta. Mereka mempunyai nilai nilai kehidupan ritual dalam menjalani aspek kehidupannya, mulai dari membuka lahan, mencari sumber air, menanam, memanen dan mendirikan rumah. Salah satu serimonial dan sakral adalah Kirab Kebo, yang diadakan setiap tahun berdasarkan perhitungan Kalender Jawa Kuno dan dikaitkan dengan memperingati Para pendiri Desa tersebut. Kirap Kebo dimulai pagi hari diiringi arak arakan sesajen hasil bumi, tari tarian dan Kerbau yang akan disembelih sepanjang jalan desa.

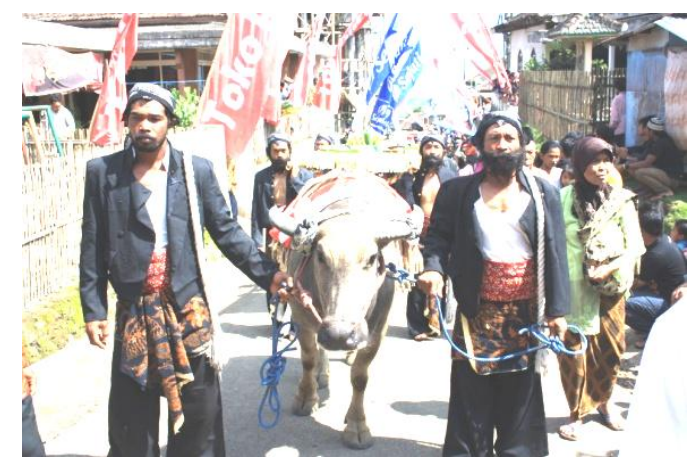

Gambar 5. Upacara kirab Kebo (Sumber: Amiuza, 2012)

\subsubsection{Penataan kluster (Cluster Arrangement)}

Permukiman masyarakat desa Bendosri berada di ketinggian $800 \mathrm{~m}$ diatas permukaan laut, yang tersusun berdasarkan kelompok kelompok hunian yang bertingkat tingkat sesuai keadaan konturnya. Mereka tersusun berhadap hadapan kemuka jalan desa. Setiap kluster pada umumnya dilengkapi dengan halaman terbuka dan kebon kebon disekeliling rumah tinggalnya.

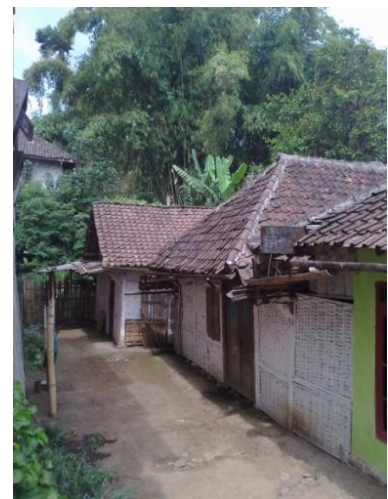

Gambar 6. Pola permukiman dlm

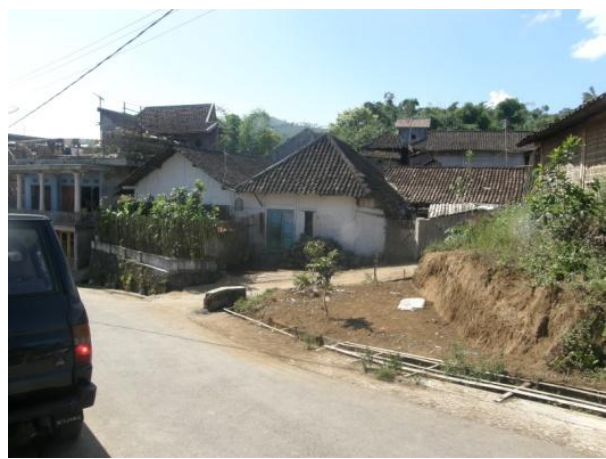

Gambar 7. Pola permukiman tepi

Jalan desa (Sumber: Amiuza, 2012)

Kluster. (Sumber: Amiuza, 2012)

\subsubsection{Sirkulasi (Circulation)}

Sirkulasi sebagai jalur jalur penghubung antara area ke area yang lain, di desa Bendosari bercirikan daerah perbukitan. Area terbawah sebagai pusat desa sampai 
area yang tertinggi lahan perkebunan dan kehutanan, jalur jalur penghubungnya berkelok kelok sesuai dengan kemiringan tanjakan pejalan kaki, meskipun kendaraan roda duapun bisa melaluinya. Pola dasar sirkulasinya linier bercabang dan medianya dari yang buatan di pusat desa sampai yang alami di permukiman dan lahan pertanian.

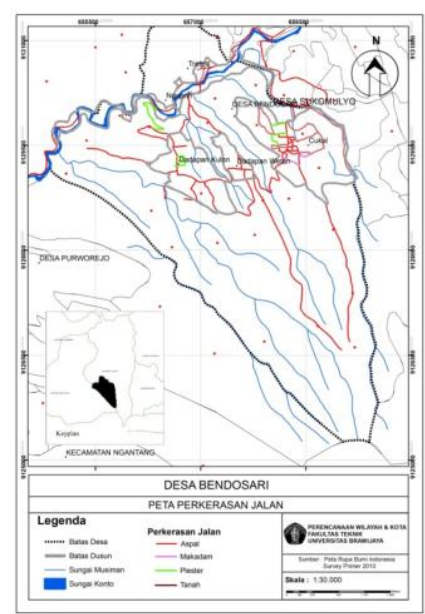

Gambar 8. Peta Sirkulasi

(Sumber: Kelurahan Bendosari)

\subsubsection{Topografi (Topography)}

Muka tanah desa bendosari yang bertingkat tingkat, umumnya banyak lahan yang sudah terbuka terutama di pusat desa dan di area permukimannya. Sedangkan di area atas juga mulai terbuka untuk lahan lahan pertanian dan perkebunan rakyat setempat, kecuali lahan hutan milik perhutani yang masih terjaga dan tertutup oleh hutan bambu dan pohon pinus.

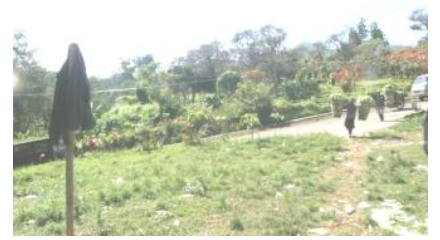

Gambar 9. Muka tanah Desa Bendoasari

(Sumber: Amiuza, 2012)

\subsubsection{Vegetasi (Vegetation)}

Desa Bendosari yang terletak di daerah pegunungan, memiliki vegetasi yang spesifik sesuai dengan iklim dan ketinggian lahannya. Tanaman pohon keras seperti, jati, nangka, pinus, mahoni dan bambu petung awalnya banyak menutupi daerah pusat desa, permukiman dan pertanian. Namun semakin lama semakin langka dan hanya tersisa di daerah kehutanan. Tanaman pohon keras tersebut umumnya dimanfatkan oleh masyarakatnya untuk permukiman tanpa perlu menanam kembali. Disamping itu terbukanya lahan lahan perkebunan dan pertanian, vegetasi yang tumbuh adalah tanaman komoditas. 


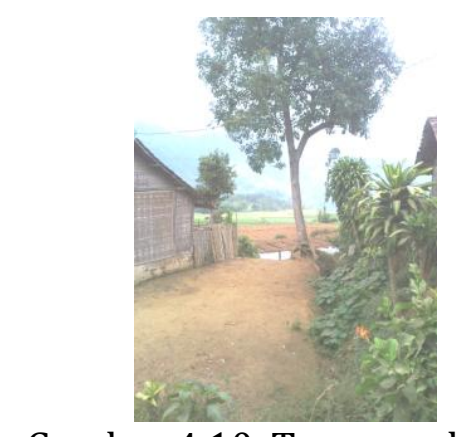

Gambar 4.10. Tanaman keras

(Sumber: Amiuza, 2012)

\subsubsection{Bangunan dan struktur (Buildings and Structures)}

Bangunan bangunan yang ada di desa Bendosari sebagian besar masih tradisional, terutama di area permukiman di pedalaman dan diatas perbukitan. Sedangkan bangunan yang ada di pusat desa sudah modern sebagaimana bangunan diperkotaan umumnya baik bentuk maupun konstruksinya. Bangunan rumah tinggal masyarakat di rea permukiman atas, dibangunan atas pondasi batu bata, kerangka bangunan dan atapnya dari kayu atau bambu, penutup dinding dari ayaman bambu dan penutup atap genteng. Bangunan bangunan Modern di pusat desa sudah mengenal konstruksi beton.

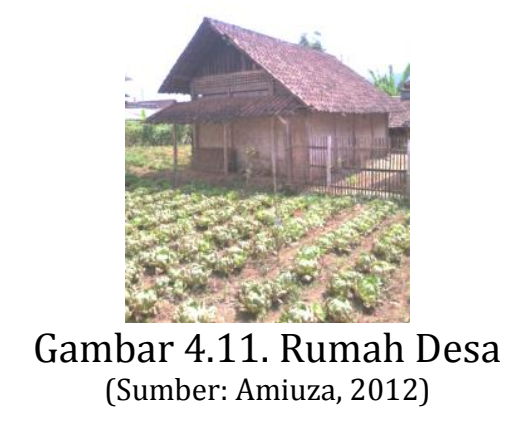

\subsubsection{View dan vista (Views and Vistas)}

Fitur-fitur alami atau buatan yang dapat menciptakan kontrol pandangan di desa Bendosari cukup beragam dan bervariasi, karena disamping pengunaan bahannya, juga tata letaknya di daerah yang konturnya berbeda beda. Pada umumnya kontrol pandangan dibentuk oleh pepohonan dan pagar pagar bambu transparan yang diselingi oleh tumbuhan pula. Mereka menciptakannya secara alami untuk kemudahan penandaan atau arah tujuan dari satu area ke area yang lain, terutama ke arah pertanian dan perkebunan mereka.

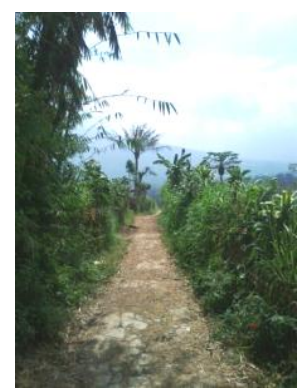

Gambar 12. View \& Vista

(Sumber: Amiuza, 2012) 


\subsubsection{Fitur-fitur air buatan (Constructed Water Features)}

Sistim Pengairan di desa telah ditata dengan baik oleh perangkat desa Bendosari, pengairan untuk persawahan, perkebunan dan permukimanya. Air didesa berasal dari beberapa sumber mata air pegunungan di sekitarnya. Ada 6 sumber air utama di desa bendosari yaitu Sumber air Ajaib, Dadapan Wetan, Ngeprih, kalianget, parang kelakah dan mutiara. Penamaan sumber sumber tersebut atas kesepakatan mereka.

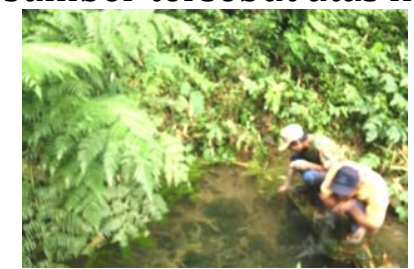

Gambar 13. Kolam Sumber Air

(Sumber: Amiuza, 2012)

\subsubsection{Fitur-fitur berskala kecil (Small Scale Features)}

Fitur-fitur berskala kecil merupakan kombinasi fungsi dan estetik dengan elemen-elemen detil yang memberikan keanekaragaman. Fitur-fitur berskala kecil ini memberikan ciri khas khusus pada keseluruhan lansekap kawasan. Desa Bendosari yang banyak memiliki tanaman Bambu, masyaraktnya memanfaatkan bahan bambu untuk fitur fitur kecil, mulai dari pos jaga, tempat mengasuh sejenah, gerbang dukuh, pagar rumah dan kebun, jembatan setapak, penahan tanjakan tanah, tiang bedera sampai ke ayunan.

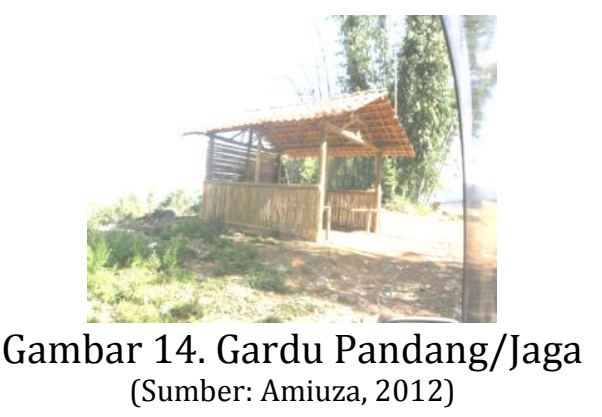

\subsubsection{Kawasan arkeologis (Archeological Sites)}

Desa Bendosari tidak termasuk desa tua yang mempunyai kawasan arkeologi. Namun bila diperhatikan ada beberapa artefak berupa rumah tradisional Gebyok yang cukup tua usianya sekitar awal perkebunan Belanda masuk desa Bendosari sekitar tahun 1920. Disamping itu ada punden tempat pemakaman pendiri desa yang berada di tengah tengah perbukitan desa, dan patung di kawasan air terjun yang tidak jelas kapan artefak tersebut dibangun.

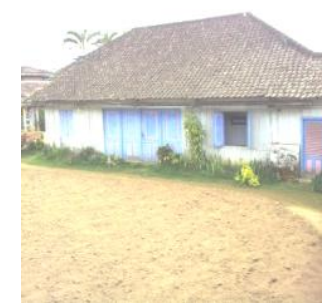

Gambar 15. Rumah Gebyok

(Sumber: Amiuza, 2012) 


\section{Kesimpulan}

Konfigurasi visual dan fisikal unsur unsur bentang alam di Desa Bendosari, kecamatan Pujon, kabupaten Malang, dapat di-gambarkan sebagai berikut:

- Sistem dan ciri alam (Natural Systems and Features) yang mempengaruhi perkembangan lansekap dan bentukan yang dihasilkan alam pada kawasan, masih didominasi alami.

- Perubahan bentuk geografinya semula perbukitan hutan menjadi area area permukiman, area persawahan, area perkebunan dan kehutanan, tertama pembukaan lahan lahan baru untuk perkebunan apel, lombok dan lobak. Sumber air yang cukup berlimpah dan bersih menjadikan lahan lahan subur dan produktif.

- Secara ekologis sebagian besar masih terjaga, namun bilaman masalah limbah manusia dan peternakan tidak segera diatasi akan terjadi degradasi ekologis. Iklim secara konsekwensi adanya bukaan lahan yang cukup besar tanpa diimbangi penanaman kembali pohon pohon asli, iklimnya sedikit berubah. Vegetasi setempat berupa pohon jati, mahoni, nagka, bambu petung banyak berkurang untuk bahan bangunan per-mukiman mereka yang digantikan oleh vegetasi perkebunan.

- Interelasi dan organisasi visual dan fisikal lingkungan alam dan lingkungan buatan pedesaan tersebut, terkait tersusun erat secara fisik, visualnya mengikuti fisik dan masih didominasi visual alami, kecuali di pusat desanya.

- Konfigurasi visual dan fisikal yang ada oleh penduduk pedesaan difungsigunakan, secara alami mengikuti kodisi alam lembah pegunungan. Pusat desanya sudah buatan dan modern, kususnya pada permukiman dan sarana jalan dan utilitasnya.

Sintaksis Bentang Alam desa Bendosari memiliki tautan yang artistik, sederhana sesuai potensi alami dan kemapuan penduduknya. Pragmatik Bentang Alam desa Bendosari memilik tautan yang berhasil-guna \& bermanfaat-guna sesuai kebutuhan peduduknya \& kondisi alamnya. Hal ini perlu dijaga dan dilestraikan, agar ekositem yang mash baik tidak menimbulkan de-gradasi alam.

Bila penentu kebijakan, pe-rencana dan perancangan pedesaan, ingin meningkatkan produktifitas desa, atau kearah pengembangan desa wisata alam, perlu kehati-hatian dan ke arifan yang menyertakan kerlibatan masyarakatnya secara luas dengan pendekatan partisipatorik.

\section{Daftar Pustaka}

Altman, Irwin. (1975). The Environment and Social Behavior: Privacy, Personal Space, Territory and Crowding. California: Brooks/Cole, Monterey.

Altman, Irwin and Chemers, Martin. (1984). Culture and Environment. California: Brooks/Cole, Monterey.

Barthes, Roland. 1997. Semiology and The Urban, diambil dari Rethinking Architecture, diedit oleh Neil Leach. London: Roudledge

Bell, Simon. (1996). Elemens of Visual Design in The Landscape. New York: Spon Press.

Carlson, Allen. (2000). Aesthetics and The environment. New York: Roudledge.

Creswell, John W. (1998). Qualitative Inquiry and Research Design. London: Sage Publications.

Dovey, Kim. (1979). The Dwelling Experience: Toward a Phenomenology of Architecture, Melbourne: University of Melbourne Press. 
Eco, Umberto. (1997). Function and Sign : The Semiotics of Architecture, diambil dari Rethinking Architecture, diedit oleh Neil Leach. London: Roudledge

Hayden, Dolores. (1997). The Power of Space : Urban Landscapes as Public History. England: The MITT Press.

Hoebel, E Adamson dan Frost, Everett L. (1976). Cultural and Social Anthrophology . New York: Mc Graw-Hill Book

Kaplan, Stephen and Kaplan, Rachel. (1998). Cognition and Environment. Van Nostrand Reinhold International.

Norbert-Schulz, Christian. (1979). Genius Loci. New York: Electa/Rizolly.

Page, Robert R., Gilbert, Cathy A., Dolan, Susan A. (1998). A guide to Cultural Landscape Reports : Contents, Process and Techniques. Washington D.C.: Government Printing Office.

Roe, Maggie \& Benson, John. (2006). Landsacape and Sustainibility. USA: Routledge

Sauer, Carl. 0. (1963). The Morphology of Landscapes dalam Land and Life. A Selection from the Writing of Carl Ortwin Sauer, diedit oleh John Leighly. Berkeley University

Selman, Paul. (2006). Planning at the landsacape Scale.

Zahnd, Markus. (1999). Perancangan Kota Secara Terpadu. Yogyakarta: Kanisius. 